\title{
Kajian Teknis dan Ekonomis Bunkering LNG untuk Pemenuhan Bahan Bakar Gas Kapal Pelni
}

\author{
Adi Mas Nizar, Ketut Buda Artana, dan Made Ariana \\ Jurusan Teknik Sistem Perkapalan, Fakultas Teknologi Kelautan, Institut Teknologi Sepuluh Nopember (ITS) \\ Jl. Arief Rahman Hakim, Surabaya 60111 Indonesia \\ e-mail: ketutbuda@its.ac.id
}

\begin{abstract}
Abstrak-Penggunaan bahan bakar gas pada bidang perkapalan merupakan suatu keuntungan karena dapat menghemat biaya operasi dan mengurangi emisi gas buang. Pemanfaatan gas juga sesuai dengan tujuan pemerintah yang terdapat pada PP No.55/2009 tentang alokasi produksi gas dalam negeri untuk penggunaan lokal sebesar $25 \%$. Proses pengisian bahan bakar (bunkering) LNG pada umumnya dapat dilakukan dengan tiga skema yaitu ship to ship, truck to ship dan onshore to ship. Untuk itu perlu dilakukan kajian untuk menentukan lokasi dan skema bunkering LNG yang akan digunakan pada studi kasus kali ini, yaitu untuk armada kapal PT. Pelni. Penentuan lokasi bunkering dilakukan dengan memperhatikan frekuensi kedatangan dan kebutuhan bunkering LNG pada setiap pelabuhan. Konversi kebutuhan bahan bakar minyak menjadi bahan bakar gas memakai asumsi bahwa motor diesel dimodifikasi menjadi duel fuel engine menggunakan konverter yang dapat dioperasikan dengan rasio bahan bakar HSD dengan LNG sebesar 50:50. Dari hasil didapatkan pada skenario I adalah Jakarta, Surabaya, Balikpapan, Makassar, Ambon dan Sorong. Skenario II dengan penambahan Bau-bau dan Skenario III dengan penambahan Jayapura. Untuk skema bunkering yang akan dipilih ditentukan dengan menggunakan metode Analytical Hierarchy Process (AHP) dengan kriteria yang dipakai diantaranya teknis, keselamatan dan biaya. Dari hasil pembobotan yang terpilih adalah skema truck to ship. Studi ditutup dengan kajian ekonomi dari sisi penyedia LNG dan dari sisi pemilik kapal. Beberapa parameter yang dipakai adalah $\mathrm{Net}$ Present Value, Internal Rate Return, dan Payback Period.
\end{abstract}

Kata Kunci-bunkering, LNG, dual fuel

\section{PENDAHULUAN}

K ONSUMSI bahan bakar minyak yang tinggi menyebabkan menipisnya cadangan minyak bumi. Kondisi ini menyebabkan penggunaan bahan bakar lain seperti gas dalam bentuk LNG, tidak terkecuali pada bidang perkapalan. Keuntungan memakai LNG selain mengurangi biaya operasi karena bahan bakar, juga dapat mengurangi emisi gas buang. Jika dibandingkan dalam satuan energi LHV, harga LNG berada di sekitar 60\% harga HFO. Tetapi bila dibandingkan dengan kebutuhan tangki bahan bakar HSD, LNG memerlukan 2.5 kali tangki yang lebih besar karena densitas yang lebih kecil dan memerlukan lapisan tambahan untuk menjaga temperatur pada kondisi $-162^{\circ} \mathrm{C}$ [1] [2].

Penggunaan LNG sebagai bahan bakar dapat mengurangi emisi karbon dioksida $\left(\mathrm{CO}_{2}\right)$ sekitar $20 \%$, nitrogen oksida $\left(\mathrm{NO}_{\mathrm{x}}\right)$ sekitar $85-90 \%$ dan sulfur oksida $\left(\mathrm{SO}_{\mathrm{x}}\right)$ hampir $100 \%$. Sesuai dengan emisi gas buang yang diperbolehkan menurut IMO dalam MARPOL Annex VI, bahan bakar LNG masih memenuhi syarat sampai dengan Tier III [1]. Penggunaan gas juga sesuai dengan tujuan pemerintah untuk memanfaatkan gas dalam negeri yang tertera pada PP. 55/2009, di mana alokasi gas bumi untuk penggunaan dalam negeri adalah $25 \%$ dari total produksi [3].

Pada studi kali ini, penggunaan bahan bakar LNG akan diaplikasikan pada 24 armada kapal penumpang milik PT. Pelni. Ilustrasi rute pelayaran yang ditunjukkan pada Gambar 1 secara umum menunjukkan banyaknya pelabuhan yang dikunjungi oleh kapal Pelni dan banyaknya kapal yang bersandar pada pelabuhan. Untuk mengimplementasikan penggunaan LNG sebagai bahan bakar pada objek studi kali ini, armada kapal Pelni memerlukan proses pengisian bahan bakar LNG di pelabuhan yang dikunjungi. Tentunya bunkering LNG tidak akan dilakukan pada setiap pelabuhan, untuk itu perlu ditentukan pelabuhan mana saja yang akan memiliki fasilitas bunkering LNG. Menurut DNV-GL, skema bunkering LNG yang telah umum banyak dioperasikan adalah onshore to ship, truck to ship, dan ship to ship [4]. Setiap skema bunkering LNG memiliki kekurangan dan kelebihan masing-masing. Untuk itu diperlukan juga pemilihan skema bunkering yang akan dipakai sesuai dengan kondisi studi kali ini

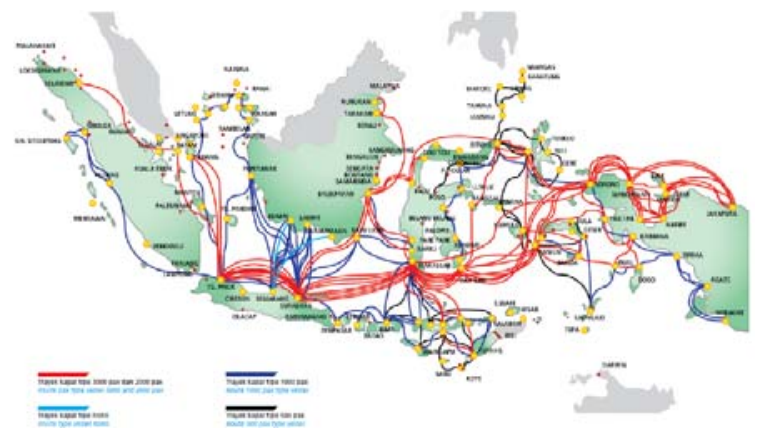

Gambar 1. Rute Pelayaran PT. Pelni dan Lokasi Pelabuhan Sumber: Annual Report Pelni 2014

\section{DASAR TEORI}

\section{A. Perhitungan Kebutuhan LNG}

Dengan menggunakan rute pelayaran PT. Pelni bulan Oktober 2015, dapat diketahui jarak tempuh dan durasi kapal berlayar dari satu pelabuhan ke pelabuhan berikutnya. Dari jarak tempuh dan durasi tersebut dapat diketahui kebutuhan bahan bakar yang dibutuhkan untuk melakukan pelayaran dari satu pelabuhan ke pelabuhan berikutnya.

Selain menghitung kebutuhan bahan bakar untuk mesin pokok, diperlukan juga perhitungan untuk kebutuhan mesin 
bantu. Karena pada kapal penumpang seperti milik PT. Pelni, kebutuhan listrik cukup besar sehingga memerlukan kapasitas mesin bantu yang besar [5].

Banyaknya konsumsi bahan bakar yang dibutuhkan dapat dihitung berdasarkan perkalian konsumsi bahan bakar spesifik mesin dengan jarak pelayaran dan besarnya daya mesin seperti ditunjukkan pada persamaan 1 .

$$
F C=B H P \times S F O C \times t
$$

Di mana

FC : Konsumsi bahan bakar (gr)

BHP : Power motor induk (kW)

SFOC : Konsumsi bahan bakar spesifik (gr/kWh)

t : Waktu (jam)

$$
Q_{H S D E n g}(M J)=L H V_{H S D}(M J / k g) \times F C(k g)
$$

Perhitungan kebutuhan LNG dalam bentuk satuan energi LHV dapat dirumuskan sebagai

$$
Q_{L N G \text { Engine }}(M J)=Q_{H S D \text { engine }}(M J) \times \text { ratio }
$$

Fuel ratio adalah perbandingan bahan bakar LNG dan bahan bakar HSD yang dipakai. Studi kali menggunakan konverter yang dapat beroperasi dengan perbandingan penggunaan bahan bakar HSD dan LNG sebesar 50:50.

$$
L N G=Q_{L N G \text { engine }}(M J) / L H V_{L N G}(M J / k g)
$$

Dalam hal konversi motor diesel berbahan bakar gas, maka kebutuhan gas dihitung dari kebutuhan energi bahan bakar. Satuan energi pada bahan bakar dapat ditunjukkan dalam bentuk Lower Heating Value (LHV) yang dimiliki masingmasing jenis bahan bakar. Untuk HSD mempunyai LHV sebesar 43.71 MJ/kg dan LNG dengan LHV 50.81 MJ/kg [6] [7].

\section{B. Analytical Hierarchy Process}

Skema bunkering di setiap pelabuhan dipilih menggunakan Analytical Hierarchy Process (AHP). Metode AHP menyelesaikan masalah multi kriteria yang kompleks menjadi salah satu hirarki, dimana hirarki adalah representasi dari sebuah permasalahan dalam struktur multi level. Level pertama berupa tujuan, diikuti oleh kriteria, sub kriteria hingga alternatif [8].

Skema bunkering yang menjadi alternatif dalam pemilihan kali ini adalah skema onshore to ship, truck to ship dan ship to ship. Opsi bunkering onshore to ship sesuai jika permintaan akan LNG bunkering besar dan rencana investasi jangka panjang. Proses bunkering ini juga dapat dimanfaatkan jika pada daerah bunkering juga terdapat konsumen lain yang memerlukan pasokan LNG. Kekurangan dari opsi ini adalah ukuran terminal untuk bunkering yang terbatas untuk ukuran kapal.

Proses bunkering dengan menggunakan metode truck to ship merupakan opsi yang efektif untuk jangka pendek jika permintaan akan bunkering LNG masih sedikit. Bunkering dengan opsi ship to ship dapat dilakukan di sepanjang dermaga ketika kapal sedang bersandar, atau mungkin ketika kapal kargo sedang lego jangkar. Opsi bunkering kapal ke kapal juga dapat dilakukan ketika kapal sedang di tengah laut. Ditinjau dari kapasitas dan lokasi bunkering yang digunakan, opsi kapal ke kapal sangat fleksibel [9].

\section{Analisa Keekonomian}

Perhitungan ekonomi berfungsi untuk mengukur apakah investasi yang akan dilakukan dapat memberikan keuntungan. Pada studi kali ini, pengukuran kelayakan investasi dilakukan dengan beberapa kriteria yaitu; NPV (Net Present Value), IRR (Internal Rate Return) dan PP (Payback Period).

\section{METODOLOGI}

Studi kali ini ditinjau dari sisi teknis dan ekonomis. Ada beberapa tahap yang dilakukan dalam studi kali ini: pemilihan lokasi, skema bunkering, desain sistem bunkering dan kajian ekonomis.

Pemilihan lokasi bunkering mempertimbangkan frekuensi berlabuh dan kebutuhan bunkering LNG pada setiap kapal pada setiap pelabuhan. Metode yang dilakukan untuk pemilihan skema bunkering menggunakan Analytical Hierarchy Process (AHP). Selanjutnya dilakukan desain untuk skema yang terpilih, yaitu P\&ID dan layout. Perhitungan juga dilakukan untuk pemasokan LNG kepada penyedia LNG. Terakhir dilakukan kajian ekonomi untuk mengetahui apakah sistem bunkering LNG yang direncanakan dapat menguntungkan atau tidak dari sisi keekonomiannya.

\section{ANALISIS DAN PEMBAHASAN}

\section{A. Frekuensi Kunjungan Kapal}

Hasil pengolahan data jadwal pelayaran armada kapal penumpang PT. Pelni yang berjumlah 24 kapal, maka didapat Tabel 1 yang menunjukkan sepuluh pelabuhan teratas.

Tabel 1. Frekuensi Kunjungan Kapal

\begin{tabular}{cc}
\hline \hline Pelabuhan & Frekuensi \\
\hline Makassar & 60 \\
Surabaya & 49 \\
Sorong & 33 \\
Bau-bau & 31 \\
Ambon & 28 \\
Tg. Priok & 25 \\
Balikpapan & 24 \\
Manokwari & 21 \\
Semarang & 20 \\
Bitung & 19 \\
\hline \hline
\end{tabular}

\section{B. Perhitungan Kebutuhan Gas}

KM. Ciremai memiliki mesin pokok berjumlah dua dengan daya masing-masing $5512.23 \mathrm{~kW}$, konsumsi bahan bakar sebesar $187 \mathrm{~g} / \mathrm{kWh}$ dan waktu tempuh dari pelabuhan Balikpapan menuju Makassar selama 15 jam. Sehingga konsumsi bahan bakar diketahui sebagai berikut.

$$
\begin{aligned}
F C_{M E} & =B H P_{M E} \times S F O C_{M E} \times t_{\text {berlayar }} \\
& =5512.23 \mathrm{~kW} \times 187 \mathrm{~g} / \mathrm{kWh} \times 15 \text { hour } \\
& =27.8 \text { ton }
\end{aligned}
$$


Konsumsi bahan bakar mesin bantu yang mempunyai spesifikasi daya sebesar $1020 \mathrm{HP}$, dengan konsumsi spesifik bahan bakar sebesar $217 \mathrm{~g} / \mathrm{kWh}$ dengan durasi pelayaran yang sama dan durasi bersandar selama 3 jam didapat hasil perhitungan sebagai berikut.

$$
\begin{aligned}
F C_{A E \text { berlayar }}= & B H P_{A E} \times S F O C_{A E} \times t_{\text {berlayar }} \\
= & (1020 \times 0.7454 \mathrm{~kW}) \times 217 \mathrm{~g} / \mathrm{kWh} \\
& \times 15 \text { hour } \\
= & 4.5 \text { ton } \\
F C_{A E \text { bersandar }} & B H P_{A E} \times S F O C_{A E} \times t_{\text {bersandar }} \\
= & (1020 \times 0.7454 \mathrm{~kW}) \times 217 \mathrm{~g} / \mathrm{kWh} \\
& \times 3 \mathrm{hour} \\
= & 0.5 \text { ton }
\end{aligned}
$$

Total kebutuhan bahan bakar yang merupakan penjumlahan dari konsumsi bahan bakar mesin induk yang berjumlah dua, tiga mesin bantu saat berlayar dan dua mesin bantu saat bersandar adalah sebagai berikut.

$$
\begin{aligned}
F C_{\text {total }} & =F C_{M E}+F C_{A E \text { Berlayar }}+F C_{A E \text { Bersandar }} \\
& =(2 \times 27.8 \text { ton })+(3 \times 4.5 \text { ton })+(2 \times 0.5 \text { ton }) \\
& =70.0 \text { ton }
\end{aligned}
$$

Dengan menggunakan persamaan sebelumnya, total kebutuhan bahan bakar HSD dikonversi menjadi jumlah dalam bentuk LNG dengan perhitungan.

$$
\begin{aligned}
Q_{H S D} & =L H V_{H S D}(M J / \mathrm{kg}) \times F C(\mathrm{~kg}) \\
& =43.71 \frac{\mathrm{MJ}}{\mathrm{kg}} \times(60.6 \times 1000 \mathrm{~kg}) \\
& =3,060,416.1 \mathrm{MJ} \\
Q_{L N G} & =Q_{H S D}(M J) \times \text { Fuel ratio } \\
& =3,060,416.1 \mathrm{MJ} \times 0.5 \\
& =1,530,208.1 \mathrm{MJ}
\end{aligned}
$$

$$
\begin{aligned}
L N G_{\text {consumption }} & =Q_{L N G}(M J) / L H V_{L N G}(M J / k g) \\
& =1,530,208.1 M J / 50.81 \mathrm{MJ} / \mathrm{kg} \\
& =30.1 \text { ton }
\end{aligned}
$$

Dari perhitungan di atas dapat diketahui untuk contoh pelayaran KM. Ciremai dari pelabuhan Surabaya menuju pelabuhan Makassar, kapal harus melakukan bunkering LNG dengan kapasitas 30.1 ton di pelabuhan Surabaya.

Perhitungan konsumsi LNG kemudian diterapkan pada setiap rute pada kapal. Tahap pemilihan lokasi mengasumsikan semua pelabuhan yang dilalui dapat melakukan bunkering LNG. Untuk KM. Ciremai sebagai contoh, dari hasil perhitungan didapatkan konsumsi LNG seperti berikut pada Tabel 2. Kebutuhan LNG pada satu pelayarannya dibedakan menjadi bunkering I ketika kapal menuju ke pelabuhan akhir dan bunkering II ketika kapal kembali menuju pelabuhan awal.

Tabel 2. Kebutuhan LNG KM. Ciremai

\begin{tabular}{lrrrr}
\hline \hline Pelabuhan & $\begin{array}{c}\text { LNG } \\
\text { (ton) }\end{array}$ & \multicolumn{1}{c}{$\begin{array}{c}\text { LNG } \\
\left(\mathrm{m}^{3}\right)\end{array}$} & $\begin{array}{c}\text { Bunkering I } \\
\left(\mathrm{m}^{3}\right)\end{array}$ & $\begin{array}{c}\text { Bunkering II } \\
\left(\mathrm{m}^{3}\right)\end{array}$ \\
\hline Tg. Priok & 2.3 & 4.9 & 58.9 & \\
Surabaya & 27.1 & 58.9 & 65.5 & 58.9 \\
Makassar & 30.1 & 65.5 & 34.1 & 65.5
\end{tabular}

\begin{tabular}{|c|c|}
\hline \multicolumn{2}{|c|}{ Skenario I } \\
\hline Pelabuhan & $\operatorname{LNG}\left(\mathrm{m}^{3}\right)$ \\
\hline Makassar & 5885.6 \\
\hline Sorong & 5383.9 \\
\hline Surabaya & 4164.5 \\
\hline Tg. Priok & 2899.7 \\
\hline Ambon & 2739.9 \\
\hline Balikpapan & 2164.3 \\
\hline \multicolumn{2}{|c|}{ Skenario III } \\
\hline Pelabuhan & LNG $\left(\mathrm{m}^{3}\right)$ \\
\hline Makassar & 4567.4 \\
\hline Surabaya & 4164.5 \\
\hline Sorong & 3618.0 \\
\hline Tg. Priok & 2899.7 \\
\hline Ambon & 2429.8 \\
\hline Balikpapan & 1853.3 \\
\hline Bau-bau & 1779.1 \\
\hline Jayapura & 1663.4 \\
\hline
\end{tabular}

\begin{tabular}{lllll} 
Bau-bau & 15.7 & 34.1 & 91.8 & 34.1 \\
Sorong & 42.2 & 91.8 & 31.4 & 91.8 \\
Manokwari & 14.4 & 31.4 & 24.5 & 31.4 \\
Serui & 11.3 & 24.5 & 44.6 & 24.5 \\
Jayapura & 20.5 & 44.6 & & 44.6 \\
\hline \hline
\end{tabular}

Kebutuhan gas pada setiap kapal dijumlahkan berdasarkan pelabuhan yang dilalui. Seleksi selanjutnya dilakukan dengan menggunakan hanya sepuluh pelabuhan teratas yang digunakan untuk bunkering LNG sehingga didapat hasil seperti pada Tabel 3.

Tabel 3. Perbandingan Urutan Kebutuhan Gas dan Frekuensi Kunjungan 10 Pelabuhan Paling Tinggi

\begin{tabular}{llllll}
\hline \hline \multirow{2}{*}{ Pelabuhan } & $\begin{array}{l}\text { Kebutuhan } \\
\text { LNG }\left(\mathrm{m}^{3}\right)\end{array}$ & & Pelabuhan & Frekuensi \\
\cline { 1 - 2 } \cline { 5 - 6 } Makassar & 4750.9 & & Makassar & 60 \\
& 3853.9 & & Surabaya & 49 \\
Tg. Priok & 2908.8 & & Sorong & 33 \\
Sorong & 2819.9 & & Bau-bau & 31 \\
Balikpapan & 2542.2 & & Ambon & 28 \\
Ambon & 2536.4 & & Tg. Priok & 25 \\
Bau-bau & 1722.7 & & Balikpapan & 24 \\
Jayapura & 1409.2 & & Manokwari & 21 \\
Manokwari & 1085.4 & & Semarang & 20 \\
Semarang & 1068.6 & & Bitung & 19 \\
\hline \hline
\end{tabular}

Pada studi kali ini akan direncanakan tiga skenario lokasi bunkering. Untuk menentukan pelabuhan mana yang akan masuk pada setiap skenario, dilakukan variasi pada jumlah pelabuhan bunkering. Skenario I terdiri dari pelabuhan Makassar, Surabaya, Tanjung Priok, Sorong, Balikpapan, Ambon. Sedangkan pada skenario II adalah enam pelabuhan pada skenario I ditambah dengan Bau-bau. Pada skenario III adalah tujuh pelabuhan pada skenario II ditambah dengan Jayapura.

Tabel 4. Perbandingan Kebutuhan Antar Skenario

\begin{tabular}{ll}
\hline \multicolumn{2}{c}{ Skenario II } \\
\hline Pelabuhan & LNG $\left(\mathrm{m}^{3}\right)$ \\
\hline Sorong & 5212.5 \\
Makassar & 4567.4 \\
Surabaya & 4164.5 \\
Tg. Priok & 2899.7 \\
Ambon & 2429.8 \\
Balikpapan & 1853.3 \\
Bau-bau & 1779.1 \\
\hline \hline
\end{tabular}

Penambahan pelabuhan pada skenario II dan skenario III mengakibatkan berkurangnya kebutuhan LNG pada beberapa pelabuhan. Dari sisi penyedia LNG, skenario yang menguntungkan adalah skenario dengan jumlah pelabuhan 
yang lebih sedikit. Dari sisi pemilik kapal, skenario yang menguntungkan adalah skenario dengan pelabuhan yang lebih banyak. Semakin banyak pelabuhan yang digunakan untuk bunkering LNG, semakin sedikit kebutuhan tangki LNG yang harus dipasang di kapal. Misal pada kapal KM. Ciremai, pada skenario I dan skenario II memerlukan 10 tangki, sedangkan pada skenario III berkurang menjadi 5 tangki

Tabel 5. Kebutuhan ISO Tank Type C 20ft

\begin{tabular}{|c|c|c|c|c|c|c|c|}
\hline Kapal & $\begin{array}{l}\mathrm{S} \\
\mathrm{I}\end{array}$ & $\begin{array}{l}\mathrm{S} \\
\mathrm{II}\end{array}$ & $\begin{array}{c}\text { S } \\
\text { III }\end{array}$ & Kapal & SI & $\begin{array}{l}\mathrm{S} \\
\mathrm{II}\end{array}$ & $\begin{array}{c}\text { S } \\
\text { III }\end{array}$ \\
\hline Awu & 8 & 8 & 8 & Lawit & 9 & 9 & 9 \\
\hline Binaiya & 6 & 6 & 6 & Leuser & 9 & 9 & 9 \\
\hline B. Raya & 6 & 6 & 6 & Nggappulu & 16 & 16 & 8 \\
\hline B.Siguntan & 8 & 8 & 8 & Pangrango & 4 & 4 & 4 \\
\hline Ciremai & 10 & 10 & 5 & Sangiang & 6 & 6 & 6 \\
\hline Dobonsolo & 11 & 11 & 6 & Sinabung & 9 & 9 & 9 \\
\hline Dorolonda & 18 & 18 & 11 & Sirimau & 14 & 14 & 14 \\
\hline G. Dempo & 9 & 9 & 5 & Tataimalu & 7 & 7 & 7 \\
\hline Kelimutu & 10 & 10 & 10 & Tidar & 12 & 12 & 12 \\
\hline Kelud & 17 & 17 & 17 & Tilongkabil & 7 & 7 & 7 \\
\hline Labobar & 17 & 17 & 9 & Umsini & 10 & 10 & 10 \\
\hline Lambelu & 8 & 4 & 4 & Wilis & 4 & 4 & 4 \\
\hline
\end{tabular}

Pemasangan tangki pada kapal mengacu pada IMO MSC.285(86) Guidelines on Safety for Natural Gas-Fuelled Enggine Installation in Ships dan dapat ditarik beberapa poin bahwa tangki LNG akan dipasang tidak pada ruang muat (kontainer) dan akomodasi. Dan jarak maksimal tangki ke sisi samping kapal adalah B/5. Pengaplikasian pada KM. Dempo misalnya, dengan menggunakan ISO Tank Type C 20ft dengan kapasitas penyimpanan LNG sebesar $20 \mathrm{~m}^{3}$, maka diperlukan sembilan tangki.

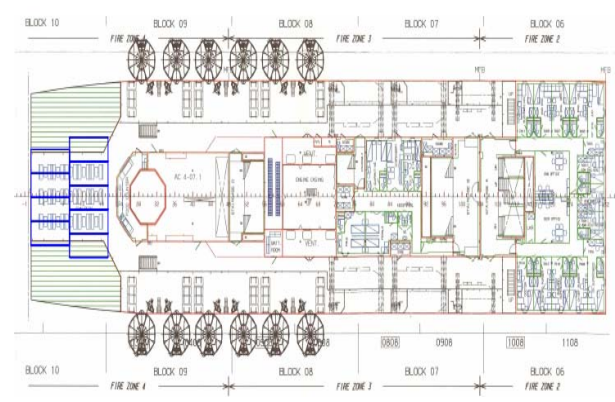

Gambar 2. Rancangan Umum KM. Dempo dengan Penempatan Tangki LNG

\section{Pemilihan Skema Bunkering}

Pada studi PT.Pelni, kapal akan melakukan bunkering ketika bersandar di pelabuhan penumpang. Karena kepadatan pelabuhan penumpang, maka opsi skema bunkering dengan menggunakan onshore to ship tidak dipakai. Misal pada pelabuhan Bau-bau seperti pada Gambar 3, terlihat baik kapal bunkering dan truk akan mengambil LNG dari terminal penerima LNG.

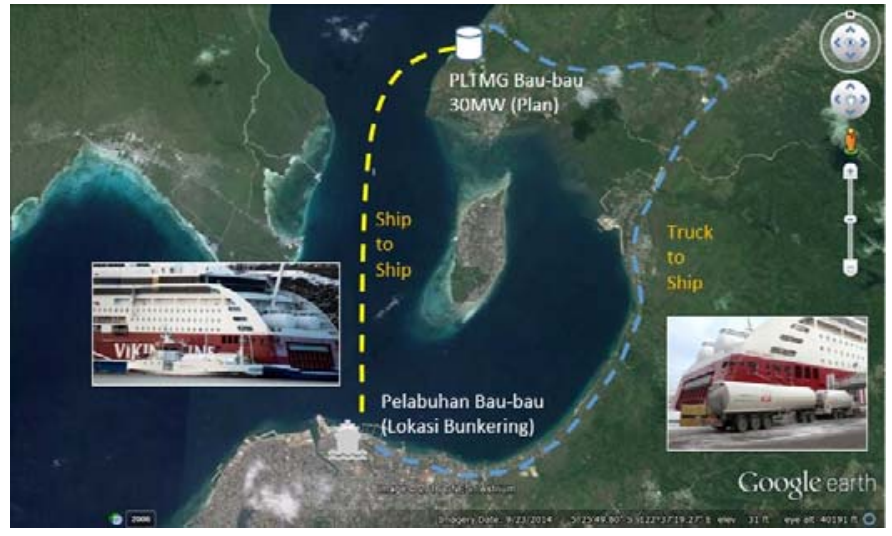

Gambar 3. Perbandingan ship to ship dan truck to ship pada pelabuhan Bau-bau

Kriteria yang dipakai pada pembobotan kali ini adalah

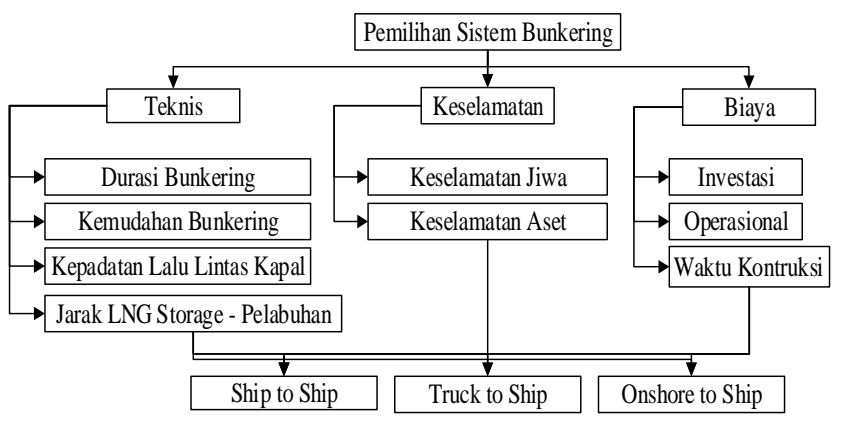

Gambar 4. Hirarki Pemilihan Skema Bunkering

Dari kriteria dan sub kriteria yang sudah ditentukan, pembobotan didapat dari hasil kuesioner yang diisi oleh responden. Pembobotan dilakukan untuk komparasi antar kriteria, antar sub kriteria pada satu kriteria, dan opsi kepada sub kriteria. Hasil dari pembobotan antar kriteria misalnya, ditunjukkan pada Gambar 5.

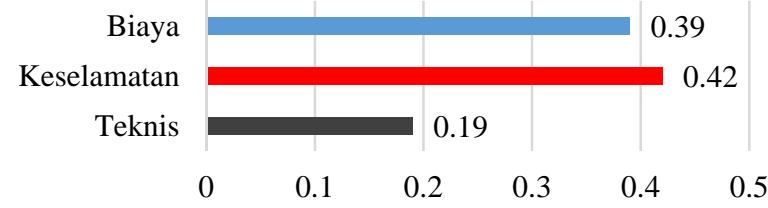

Gambar 5. Pembobotan Kriteria

Dari hasil pengolahan, didapat hasil seperti pada yang ditunjukkan grafik performance sensitivity seperti pada Gambar 6. Hasil dari pembobotan mendapatkan opsi skema truck to ship. Ditunjukkan pada grafik, skema truk to ship memiliki nilai pembobotan lebih tinggi pada kriteria teknis dan biaya. Grafik sensitivitas juga menunjukkan jika nilai salah satu kriteria dirubah pada kondisi 100\%, 50\% dan 0\%, alternatif yang terpilih tetap skema truck to ship. 


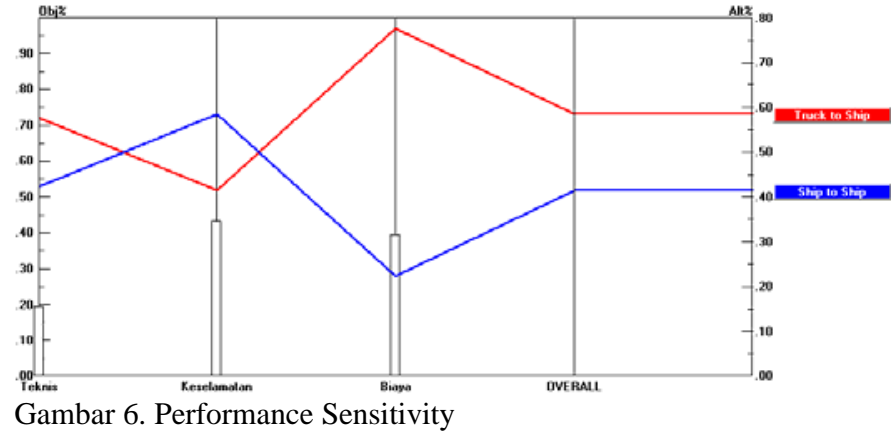

D. Desain Fasilitas Bunkering

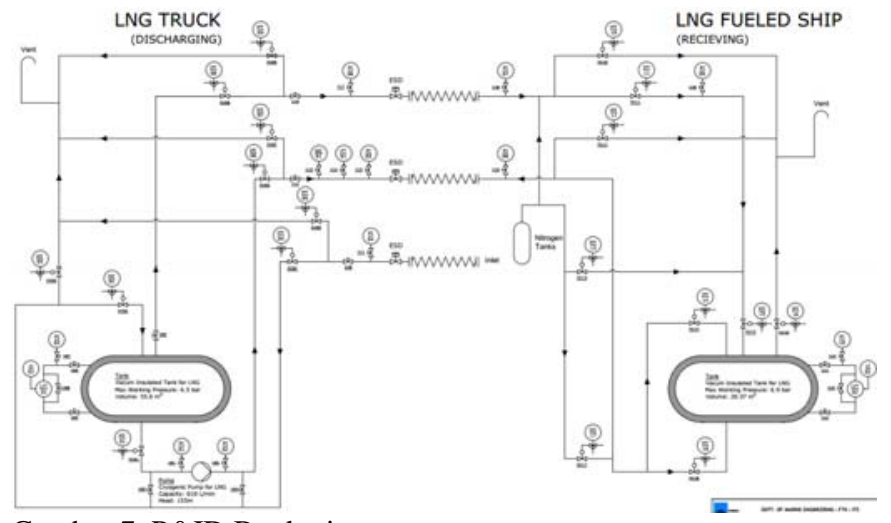

Gambar 7. P\&ID Bunkering

Secara garis besar proses bunkering dimulai dari proses precooling, yang bertujuan untuk mengkondisikan semua komponen yang akan dilewati aliran LNG tidak mengalami keretakan ketika LNG dialirkan. Proses selanjutnya adalah inerting, inerting dilakukan dengan menggunakan gas inert yang bertujuan untuk menghilangkan oksigen dan gas uap pada saluran pipa. Oksigen dan gas uap dihilangkan agar tidak terbentuk hydrat nantinya. Setelah inerting dilakukan, gas nitrogen yang dipakai pada proses inerting dibuang pada proses purging dengan menggunakan gas natural. Selanjutnya proses pengisian dapat dilakukan baik dengan menggunakan pengisian atas dan bawah tangki. Setelah proses pengisian selesai dilakukan, dilakukan stripping guna menguras LNG yang tersisa.

Dari delapan pelabuhan bunkering yang terpilih, akan dibagi menjadi dua cluster. Cluster I akan memasok LNG dari Badak LNG untuk terminal penerima yang ada di Tanjung Priok, Surabaya, Balikpapan, Makassar dan Bau-bau. Sedangkan cluster II akan memasok LNG dari Tangguh LNG untuk terminal penerima yang ada di Ambon, Sorong dan Jayapura.

Dari perhitungan lama kapal pemasok LNG untuk menempuh roundtrip pada setiap clusternya, cluster I akan dipasok dengan LNG Tanker dengan ukuran $7500 \mathrm{~m}^{3}$ dan cluster II dengan ukuran $2500 \mathrm{~m}^{3}$. Lama roundtrip setiap LNG tanker mempengaruhi banyaknya tangki LNG yang akan dipasang pada terminal penerima. Dari hasil perhitungan dengan menetapkan tangki yang akan dipasang adalah ukuran $300 \mathrm{~m}^{3}$, maka Tabel 6 menunjukkan banyaknnya tangki yang diperlukan pada masing-masing pelabuhan pada masingmasing skenario.
Tabel 6. Kebutuhan Tangki LNG

\begin{tabular}{lccc}
$\begin{array}{c}\text { Terminal } \\
\text { (Pelabuhan) }\end{array}$ & Skenario I & Skenario II & Skenario III \\
\hline Jakarta & 3 & 3 & 3 \\
Surabaya & 4 & 5 & 5 \\
Balikpapan & 2 & 3 & 3 \\
Makassar & 6 & 5 & 5 \\
Bau-bau & - & 2 & 2 \\
Ambon & 2 & 2 & 3 \\
Sorong & 4 & 3 & 4 \\
Jayapura & - & - & 2 \\
\hline \hline
\end{tabular}

Dari beberapa kebutuhan yang berbeda-beda setiap skenario pada setiap pelabuhannya, makan layout yang digunakan dikelompokkan pada beberapa kategori: I (1-2 tangki), II (3-4 tangki), II (5-6) yang masing-masing memerlukan luas tanah yang berbeda-beda. Misal Gambar 8 menunjukkan layout untuk kategori III dan Gambar 9 menunjukkan dalam bentuk tiga dimensi.

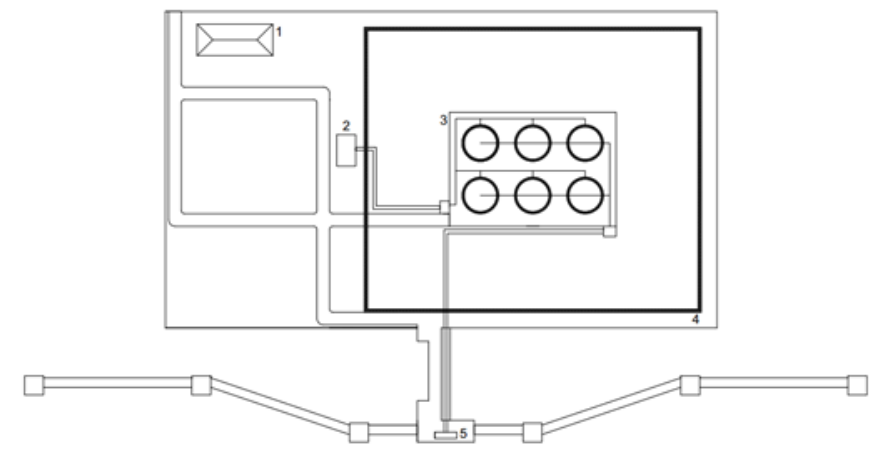

Gambar 8. Layout Terminal Penerima Kategori III

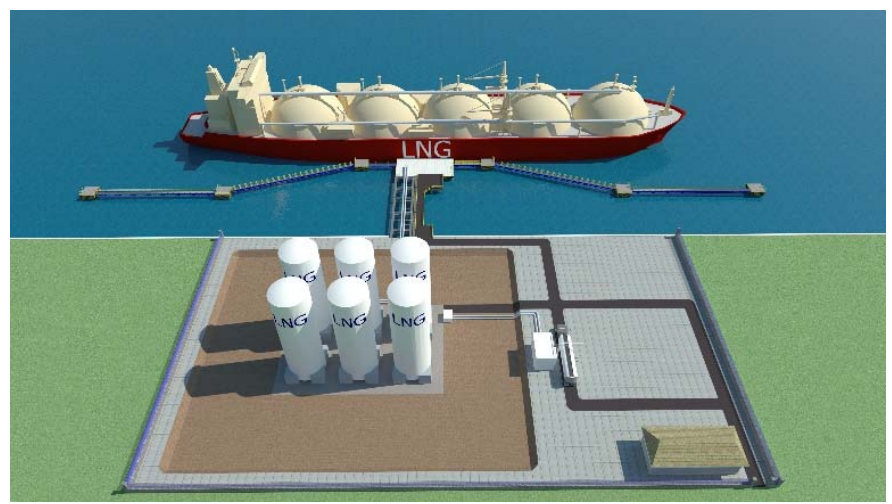

Gambar 9. Layout Terminal Penerima Kategori III (3D)

\section{E. Kajian Ekonomi}

Kajian ekonomi pada studi kali ini dibagi menjadi dua, satu dari sisi penyedia LNG, dan satu dari sisi pemilik kapal. Terdapat dua vaiabel dalam kajian ekonomi, yaitu Capital Expenditure (CAPEX) dan Operational Expenditure (Opex). Capex adalah investasi yang dikeluarkan untuk pembelian dan pembangunan fasilitas. Sedangkan Opex adalah biaya yang harus dikeluarkan perusahaan setiap tahunnya untuk operasional. Capex dari sisi penyedia LNG diantaranya adalah pembangunan terminal penerima LNG dan pengadaan truk LNG. Sedangkan Capex dari sisi pemilik kapal adalah biaya modifikasi mesin kapal dan pengadaan LNG ISO Tank. Opex 
pada penyedia gas adalah biaya sewa LNG tanker, biaya operasional fasilitas penerima LNG.

Pemasukan (revenue) dari penyedia LNG didapat dari margin antara pembelian dan penjualan LNG. Pada studi kali ini terdapat empat variasi margin yang digunakan yaitu ketika margin US\$3, US3,5, US\$4 dan US\$4,5. Nilai margin kemudian dikalikan dengan banyaknya LNG yang dijual setiap tahunnya. Sedangkan pemasukan dari sisi pemilik kapal adalah penghematan yang dilakukan karena penggunaan LNG. Selisih tadi dikurangi dengan kerugian karena kehilangan muatan akibat pemasangan tangki ISO LNG tank.

Perhitungan dilakukan dengan memasukkan nilai suku bunga, pajak, inflasi dan sebagainya. Biaya tersebut digunakan karena $50 \%$ dari biaya investasi yang direncanakan berasal dari pinjaman bank. Besar suku bunga ditentukan sebesar $10.25 \%$. Sedangkan besar nilai pajak yang harus dibayarkan setiap tahunnya mengacu pada Peraturan Pemerintah Republik Indonesia No. 46 Tahun 2013 tentang pajak penghasilan.

Dari hasil perhitungan dari sisi penyedia LNG dan pemilik kapal, didapatkan masing-masing nilai IRR, NPV dan PP seperti ditunjukkan pada Tabel 7 dan Tabel 8.

Tabel 7. Keekonomian Penyedia LNG Pada Skenario Bunkering III

\begin{tabular}{rrrrrrr}
\hline & $\begin{array}{c}\text { LNG } \\
\text { Beli }\end{array}$ & $\begin{array}{r}\text { LNG } \\
\text { Jual }\end{array}$ & Pemasukan & NPV & IRR & PP \\
\hline $\mathrm{A}$ & $\$ 8$ & $\$ 11$ & $\$ 22,417,481$ & $\$(17,202,502)$ & $1 \%$ & $>20$ \\
$\mathrm{~B}$ & $\$ 8$ & $\$ 11.5$ & $\$ 26,153,728$ & $\$ 15,114,910$ & $8 \%$ & 14.1 \\
$\mathrm{C}$ & $\$ 8$ & $\$ 12$ & $\$ 29,889,974$ & $\$ 47,416,138$ & $14 \%$ & 7.9 \\
$\mathrm{D}$ & $\$ 8$ & $\$ 12.5$ & $\$ 33,626,221$ & $\$ 79,706,575$ & $29 \%$ & 5.7 \\
\hline \hline
\end{tabular}

Tabel 8. Keekonomian Pemilik Kapal Pada Skenario Bunkering III

\begin{tabular}{lllllll}
\hline \hline & LNG & HSD & Pemasukan & \multicolumn{1}{c}{ NPV } & IRR & PP \\
\hline A & $\$ 11$ & $\$ 0,55$ & $\$ 19,581,291$ & $\$ 113,045,272$ & $36 \%$ & 3.0 \\
B & $\$ 11.5$ & $\$ 0,55$ & $\$ 16,099,917$ & $\$ 72,975,253$ & $26 \%$ & 4.3 \\
C & $\$ 12$ & $\$ 0,55$ & $\$ 12,618,543$ & $\$ 32,905,233$ & $15 \%$ & 7.4 \\
D & $\$ 12.5$ & $\$ 0,55$ & $\$ 9,137,170$ & $\$(7,164,786)$ & $2 \%$ & $>20$ \\
\hline \hline
\end{tabular}

Payback period yang harus dipenuhi adalah di bawah 20 tahun sesuai perhitungan umur proyek ini. Dari penyedia LNG, semakin besar margin akan mempersingkat payback periode, tetapi dari pemilik kapal dengan semakin mahalnya harga LNG dengan harga HSD tetap akan memperbesar payback periode.

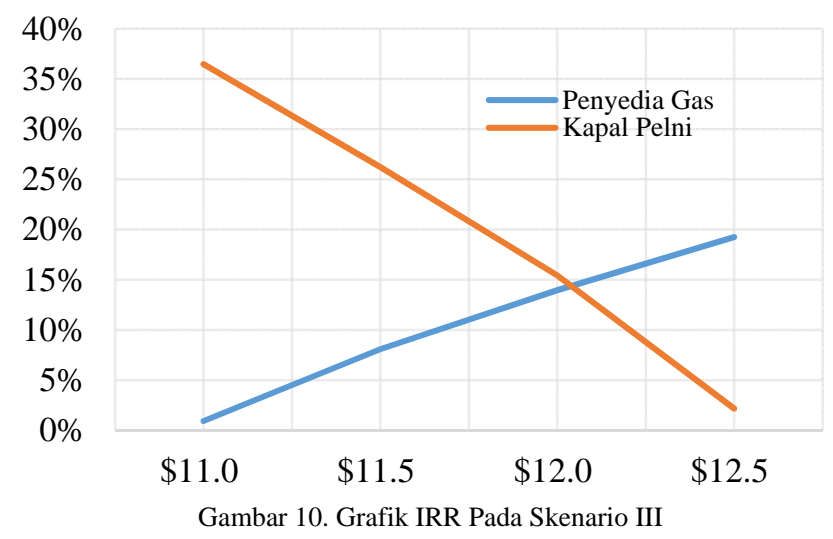

Sehingga pada Tabel 10 ditunjukkan perbadingan IRR pada peningkatan harga LNG. Dari grafik diketahui bahwa penyedia LNG dan pemilik kapal akan mendapatkan nilai IRR yang sama pada nilai harga jual dan beli LNG \$12,05.

\section{KESIMPULAN}

Berdasarkan studi yang telah dilakukan, maka dapat disimpulkan sebagai berikut:

1. Lokasi bunkering diurutkan menjadi tiga skenario. Skenario I memakai Tanjung Priok, Surabaya, Balikpapan, Makassar, Ambon dan Sorong sebagai lokasi bunkering. Skenario II memakai enam pelabuhan pada skenario I ditambah dengan pelabuhan Bau-bau. Skenario III memakai tujuh pelabuhan pada skenario II ditambah dengan pelabuhan Jayapura.

2. Skema bunkering LNG yang dipakai pada setiap pelabuhan adalah Truck to Ship. Truk LNG dengan kapasitas $50 \mathrm{~m}^{3}$ akan mengangkut LNG dari terminal penerima menuju pelabuhan bunkering.

3. Skenario bunkering I pada setiap variasi margin (\$3, \$3.5, \$4, \$4.5) menghasilkan payback di bawah 20 tahun, tetapi nilai IRR terpenuhi pada margin minimal \$3.5. Sedangkan skenario bunkering II dan III menghasilkan payback period di bawah 20 tahun pada margin minimal \$3.5.

\section{DAFTAR PUSTAKA}

[1] J. Herdzik, "LNG As A Marine Fuel - Possibilities And Problems," KONES Powertrain and Transport, vol. 18, 2011.

[2] S. dan K. B. Artana, Transportasi LNG Inonesia. Surabaya: Airlangga University Press, Surabaya: Airlangga University Press, 2005.

[3] K. ESDM, Kebijakan Alokasi Gas Bumi Untuk Dalam Negeri, Jakarta, 2014.

[4] DNV, “Liquefied Natural Gas (LNG) Bunker Study," Maritime Administration, 2014.

[5] M. F. Rochyana, M. Y. Jinca dan J. Siahaya, "MDO and LNG as Fuels (Duel Fuel) to Support Sustainable Maritime Transport (A Case Study in KM. Ciremai)," International Refereed Journal of Engineering and Science (IRJES), vol. 3, pp. 32-38, 2014.

[6] Syukran dan D. Suryadi, "Estimasi Penghematan Biaya Operasi PLTU dengan Cara Penggantian Bahan Bakar,” Jurnal Teknik Mesin, vol. 9, pp. 59-66, 2007.

[7] M. R. Fitra, Studi Kelayakan Konversi Diesel Engine Berbahan Bakar Minyak Menjadi Dual Fuel Diesel Engine Pada Kapal Container 368 TEU, Surabaya: Teknik Sistem dan Pengendalian Kelautan, 2015.

[8] K. B. Artana, "Pengambilan Keputusan Kriteria Jamak (MCDM) untuk Pemilihan Lokasi Floating Storage and Regasification Unit (FSRU): Studi Kasus Suplai LNG dari Ladang Tangguh ke Bali,” Jurnal Teknik Industri , vol. 10, pp. 97-111, 2008.

[9] M. Ariana, G. Saputro dan D. Priyanta, "Kajian Pemilihan Lokasi, Opsi, Dan Desain Sistem Bunkering LNG Untuk Bahan Bakar Kapal Di Alur Pelayaran Barat Surabaya,” dalam Seminakel X, Surabaya, 2015. 